\title{
W POSZUKIWANIU CIERPIENIA ZWIERZĄT. O POLSKIEJ I ROSYJSKIEJ NAJNOWSZEJ POEZJI KOBIET ${ }^{1}$
}

\author{
AgniesZKa KWIATKOWSKA ${ }^{2}$ \\ (Uniwersytet im. Adama Mickiewicza w Poznaniu)
}
Słowa kluczowe: posthumanizm, animal studies, cierpienie zwierząt, Justyna Bargielska, Wisława Szymborska, poezja rosyjska
Keywords: post-humanism, animal studies, animal suffering, Justyna Bargielska, Wisława Szymborska, Russian poetry

\begin{abstract}
Abstrakt: Agnieszka Kwiatkowska, W POSZUKIWANIU CIERPIENIA ZWIERZĄT. O POLSKIEJ I ROSYJSKIEJ NAJNOWSZEJ POEZJI KOBIET. „PORÓWNANIA” 2 (21), 2017, S. 127-136. ISSN 1733-165X. Kryzys hermeneutyki i zwrot w badaniach antropologicznych sprzyjają budowaniu nieantropocentrycznej, posthumanistycznej perspektywy, rekonstruowaniu w literaturze zwierzęcej percepcji i zwierzęcych doświadczeń, między innymi cierpienia. Polska najnowsza poezja kobiet (między innymi Justyny Bargielskiej i Wisławy Szymborskiej) ukazuje zwierzęta jako ofiary ludzkiej opresji oraz istoty do człowieka podobne. Empatii często towarzyszy antropomorfizacja. W poezji kobiet pisanej w języku rosyjskim motyw cierpienia zwierząt występuje stosunkowo rzadko. Dominuje w niej perspektywa globalna (nie jednostkowa), a kategoria cierpienia zarezerwowana jest dla zbiorowości (społeczeństwa, narodu). Cierpienie jest przymiotem ludzi, a nie zwierząt między innymi w poezji Olgi Siedakowej, Reginy Dieriewej, Lubow Salomon czy Olgi Lewickiej.
\end{abstract}

Abstract: Agnieszka Kwiatkowska, THE DEPICTIONS OF ANIMAL SUFFERING IN THE NEWEST POLISH AND RUSSIAN WOMEN'S POETRY. "PORÓWNANIA" 2 (21), 2017, P. 127-136. ISSN 1733-165X. The crisis of hermeneutics and the turnabout in anthropological research are conducive to the development of non-anthropocentric, post-humanist perspective and the reconstruction of the animal viewpoint and experience in animal literature, among others, suffering. The most recently published Polish women's poetry (among others by Justyna Bargielska and Wisława Szymborska) portrays animals as the victims of human oppression and beings similar to humans. Empathy is often accompanied by anthropomorphism. In the women's poetry written

1 Artykuł powstał w ramach realizacji grantu "Stulecie poetek polskich" (UMO-2015/17/B/ HS2/01245).

2 E-mail: agak@amu.edu.pl 
in Russian, the motif of animal suffering appears rather infrequently. A global (not individual) perspective dominates in poems, while the category of suffering is reserved for the collectivity (society or nation). Suffering is a human and not animal trait in the poetry of Olga Siedakowa, Regina Dieriewa, Lubow Salomon, Olga Lewicka and others.

Cierpienie człowieka łatwiej jest mi znieść niż cierpienie zwierzęcia. Człowiek ma własny, rozbudowany, rozgłoszony wszem i wobec ontologiczny status, co czyni go gatunkiem uprzywilejowanym. Ma kulturę i religię, żeby go wspierały w cierpieniu. [...] Ludzkie cierpienie ma sens. Dla zwierzęcia nie ma ani pociechy, ani ulgi, bo nie czeka go żadne zbawienie. Nie ma tez sensu. Ciało zwierzęcia nie należy do niego. Duszy nie ma. Cierpienie zwierzęcia jest absolutne, totalne (Tokarczuk 31).

Tak pisała Olga Tokarczuk w jednym z felietonów. Dalej, budując posthumanistyczną, nieantropocentryczną perspektywę, dodała:

Jeżeli spróbujemy wejrzeć w ten stan z naszą ludzką zdolnością do refleksji i ze współczuciem - odkryje się cała groza zwierzęcego cierpienia, a tym samym przerażająca, trudna do zniesienia groza świata (Tokarczuk 32).

Kryzys hermeneutyki postmodernistycznej oraz zapoczątkowany przez Michela Foucaulta ${ }^{3}$ zwrot w badaniach antropologicznych, w których coraz częściej zaczęło dochodzić do łączenia nauk biologicznych i społecznych, sprzyjają budowaniu nieantropocentrycznej perspektywy, rekonstruowaniu zwierzęcej percepcji, doświadczeń, także analizowaniu zwierzęcego cierpienia w nowym, posthumanistycznym ujęciu. Historia człowieka, jego myśli i osiągnieć - zaznaczał Foucault jest krótka i możliwe, że zbliża się ku końcowi (Foucault 347). W dobie kryzysu antropocentryzmu pojawiła się więc potrzeba nowego postrzegania podmiotowości, która musi być przypisana również innym, nieludzkim formom życia. Tak postrzegany posthumanizm - uprawiany między innymi przez Cary'ego Wolfe'a - staje się $\mathrm{w}$ gruncie rzeczy humanizmem rozszerzonym, który rezygnuje $\mathrm{z}$ dotychczasowej elitarności i zaczyna swoimi ideami obejmować nie tylko świat ludzki, ale również królestwo roślin i zwierząt. Fundamentalną dla formacji sentencję Terencjusza należałoby wówczas przeformułować i rozszerzyć na przykład tak: jestem istotą żywą (i nic co właściwe życiu, nic co życiowe, nie jest mi obce).

3 Michel Foucault (autor tak ważnych prac jak Narodziny kliniki 1963, Nadzorować i karać 1975, Historia seksualności 1976 ) przedstawił między innymi koncepcję biopolityki, która zakłada daleko posuniętą korelację życia biologicznego z funkcjonowaniem społecznym, wpływ pragnień cielesnych jednostek na życie polityczne społeczeństwa (wynikające z tradycji kultury Zachodu zalecającej kontrolę nad pragnieniami cielesnymi i seksualnością w celu kontroli populacji oraz z arystotelesowskiej koncepcji człowieka postrzeganego jako zwierzę obdarzone skłonnością do życia politycznego/społecznego). Foucault nie używa terminu posthumanizm, ale jego myśl to podwaliny posthumanistycznych idei. 
Współcześnie posthumanizm to dziedzina niezwykle polifoniczna, która doskonale łączy się z różnymi ujęciami literatury, między innymi z animal studies, gender studies czy krytyką feministyczną, a sam motyw cierpienia zwierząt szczególnie często pojawia się dziś w pisarstwie kobiet. Tendencja do empatii, uruchamiania nieantropocentrycznej i niepatriarchalnej perspektywy, podważanie układów hierarchicznych uzasadniających systemy opresyjne stały się istotnym elementem kobiecej twórczości.

Zwierzęta, podobnie jak dzieci, szaleńcy, odmieńcy i oczywiście kobiety zaliczają się do niepatriarchalnego zbioru jednostek, które nie są „mężczyznami u władzy", opisywanego między innymi przez Ewę Kraskowską. Konstruując kategorię czytelniczki, badaczka pisała:

Hipoteza czytelnika kobiecego jest zatem równoznaczna z wprowadzeniem innej (w języku patriarchatu - dziwnej, nietypowej, niezwykłej itp.) perspektywy odbioru i oceny danego komunikatu. [...] Dziecko w świecie dorosłych, wariat między zdrowymi na umyśle, Guliwer w kraju olbrzymów, Marsjanin na Ziemi - wszyscy oni, widząc inny wymiar „zwykłych” rzeczy i zdarzeń, podają w wątpliwość ustalony porządek świata. Do nich dołączyła kobieta (Kraskowska 33).

Podobnym uniezwykleniem jest wprowadzenie animalnego punktu widzenia, próba empatycznego zrekonstruowania oglądu świata z perspektywy zwierząt czy nawet roślin, podważająca porządek nie tylko patriarchalny, ale i antropocentryczny. Cierpienie zwierząt - traktowane jako cierpienie innego, który jednak nie do końca pozostaje obcy - spotyka się więc ze szczególnym zainteresowaniem wielu pisarek, a poświęcana mu uwaga staje się jednym z wyróżników kobiecego oglądu świata.

W literaturze przedmiotu znajdziemy wiele studiów poświęconych cierpieniu zwierząt w prozie kobiet. Kraskowska analizuje pod tym kątem pisarstwo Zofii Nałkowskiej (w monografii Piórem niewieścim), Arleta Galant śledzi opisy śmierci zwierząt we współczesnej prozie ( $\mathrm{w}$ artykule zamieszczonym $\mathrm{w}$ tomie Twórczość niepozorna). W poezji - która rzadziej bywa mimetyczna, a obfitość metafor i chwytów artystycznych zdaje się budować większy dystans pomiędzy światem a tekstem - postaci zwierząt, także ich doświadczenia i model postrzegania świata, często przynależą raczej do sfery signifiant niż signifié. Uruchomienie posthumanistycznej perspektywy odbioru oraz łączenie badań literaturoznawczych z ujęciami socjologicznymi czy zaangażowaniem ideowym wymaga wówczas szczególnej ostrożności ze strony badacza. Aż nadto wyraźnie widać to w poezji Wisławy Szymborskiej, gdzie enumeracja, anafora, paronomazja czy polisyndeton stają się próbami językowego uporządkowania chaosu istniejącego w naturze (Ładyga, Włodarczyk 45). Zarówno animal studies, jak i studia genderowe w swym akademickim wymiarze są blisko powiązane z ruchami społecznymi (obrońców praw zwierząt, walki z dyskryminacją na tle płci), a wielu badaczy dostrzega analogie pomiędzy formami opresji funkcjonujący- 
mi w systemie społecznym wobec ludzi i zwierząt, na przykład miedzy seksizmem a szowinizmem gatunkowym, choć ujęcie takie niewątpliwie prowadzi do daleko idących uproszczeń (Ładyga, Włodarczyk 18).

Uwzględniając te zastrzeżenia, można jednak $\mathrm{w}$ najnowszej polskiej poezji kobiet wyróżnić trzy zasadnicze modele wprowadzenia bohatera zwierzęcego, doświadczającego szeroko pojętego cierpienia. W pierwszym z nich zwierzęce odczucia są kontrapunktem, który umożliwia pokazanie humanoidalnej perspektywy lub służy charakterystyce człowieka. Tak dzieje się w wielu utworach Szymborskiej, na przykład w słynnym wierszu Kot w pustym mieszkaniu, gdzie niepojęty, niemal absurdalny charakter śmierci jest przecież doświadczeniem zasadniczo ludzkim, czy w liryku Monolog psa zaplątanego w dzieje (z tomu Dwukropek), w którym cierpienia tytułowego bohatera tak naprawdę ukazują bezwzględny charakter mechanizmów historii i okrucieństwo człowieka, ustalającego zasady hierarchizacji (a co za tym idzie, także przyzwolenie na opresyjność).

Sprawcą cierpienia (zarówno ludzkiego, jak i zwierzęcego) w większości opisywanych w poezji Szymborskiej przypadków (także we wcześniejszych wierszach) jest człowiek, który w stosunku do świata fauny i flory przyjmuje postawę kolonialną. Koniczność przełamania impasu w komunikacji międzygatunkowej podkreślana jest choćby w wierszu Obmyślam świat (gdzie pierwszym rozdziałem nowo projektowanego świata jest Mowa Zwierząt $i$ Roślin) czy Tarsjusz (z tomu Sto pociech), gdzie podniosły monolog małpki nie tylko służy wyrażeniu opresji świata zwierząt, ale też podkreśla chwilowość, wyją̨tkowość, pewną sztuczność sytuacji, w której zwierzęciu udzielono głosu (Ładyga, Włodarczyk 51).

Drugi model podkreśla podobieństwo ludzi i zwierząt, uwypukla wspólne elementy w przeżywaniu cierpienia, jak strach przed bólem czy zagrożenie śmiercią. $\mathrm{Z}$ takim ujęciem mamy do czynienia na przykład w poezji Justyny Bargielskiej, gdzie potrącony pies - ofiara wypadku drogowego - nie tylko staje się pretekstem do rozmyślań o ludzkiej kruchości i śmiertelności, ale zostaje niejako zrównany z człowiekiem poprzez egalitarny charakter doświadczenia śmierci. Bargielska chętnie pokazuje, że śmierć przekracza granice gatunkowe i że - co już nie takie oczywiste w kulturze - jest tak samo odczuwana przez byty ludzkie i nieludzkie. Takie ujęcie pozwala poetce osadzić tak ważne w jej twórczości poronienie w kategorii doświadczenia śmierci tak samo istotnej, o wadze niezdeterminowanej ani stopniem zaawansowania ciąży, ani poglądami osób doznających straty.

W trzecim modelu zwierzęta stają się odrębnymi od człowieka bohaterami, a próba zrekonstruowania ich percepcji równie często wiąże się z uruchomieniem równorzędnej wobec ludzkiego myślenia nieantropocentrycznej perspektywy, jak i z przyjęciem postawy franciszkańskiej, niewolnej od poczucia wyższości generującego troskę i opiekuńczość wobec bytów niższych. Empatia i tendencja do antropomorfizacji nie wykluczają się wzajemnie, niejednokrotnie współistnieją w próbie rozszerzenia oglądu i odbioru świata. Przykładem mogą tu być wiersze Uty Przyboś, któ- 
re należałoby rozpatrywać $\mathrm{w}$ duchu animal studies ze świadomością, że poetka łączy twórczość literacką z zaangażowaniem społecznym i działaniem na rzecz zwierząt.

Nieuniknione antropomorfizacje połączone $\mathrm{z}$ budowaniem empatii można uznać za dowód na istnienie ponadgatunkowej wspólnoty odczuwania. Szymborska w felietonie poświęconym Opowiadaniom o zwierzętach Konrada Lorenza pisała: „[...] to, co wszechludzkie, jest niemal zawsze czymś przedludzkim. Nasze uczucia i sposoby postępowania są kontynuacją i rozwinięciem wątków cudownie już zapoczątkowanych w świecie zwierzęcym" (cyt. za: Ładyga, Włodarczyk 48). To, co w zachowaniu zwierząt postrzegamy jako ludzkie, w istocie jest pierwotne i wspólne nam wszystkim. To dlatego w poezji Szymborskiej tak często pojawia się małpa „wcześniej niż ludzie wygnana z raju”, niejednokrotnie dzieląca niedolę ludzkiego losu (Ładyga, Włodarczyk 49).

W poezji kobiet pisanej w języku rosyjskim motyw cierpienia zwierząt występuje stosunkowo rzadko, a samo wyodrębnienie specyficznych cech tej gałęzi literatury w świadomości rosyjskiego odbiorcy rysuje się dość słabo. W powszechnym odczuciu pisarstwo kobiet postrzegane jest w układzie binarnym jako opozycja twórczości męskiej. Tymczasem w myśli zachodnioeuropejskiej coraz wyraźniej zaznacza się postrzeganie pisarstwa kobiet jako dziedziny literatury uruchamiającej specyficzną estetykę czy realizującej szczególne normy, zauważalnej nie tylko w kontraście wobec męskiej (patriarchalnej czy tradycyjnej) skali wartości. Wydaje się, że w powszechnej świadomości społeczeństwa rosyjskiego określenie „twórczość kobieca” postrzegane jest wciąż jako deprecjonujące. To dlatego nawet młode krytyczki literatury (na przykład poetka i filozofka Ałła Gorbunowa czy dziennikarka i poetka Maria Bańko) mówią o zjawisku poezji kobiecej z dużą ostrożnością.

Gorbunowa woli postrzegać poezję jako uniwersalną dziedzinę, dostępną w takim samym stopniu kobietom i mężczyznom. Sprzeciwia się budowaniu opozycji twórczości kobiecej (postrzeganej jako pisarski ekwiwalent ręcznych robótek) i męskiej (której przypisuje się cechy sztuki monumentalnej) (The devochki - źródło elektroniczne) ${ }^{4}$. Pomija - tak wyraźny między innymi w poezji polskiej - problem niedopasowania kobiet do usankcjonowanego tradycją modelu historii literatury, a zwraca uwagę na związki ich twórczości z tendencjami historycznoliterackimi, powiązania $\mathrm{z}$ ugrupowaniami poetyckimi, dialog z powstającą $\mathrm{w}$ tym samym czasie twórczością mężczyzn. Bańko wymienia nazwiska i komentuje: „, to piękne przykłady poezji kobiet, na szczęście nie "poezji kobiecej»" (Bańko). Drugie określenie wzięte jest w cudzysłów, sygnalizujący dystans krytyczki do tego terminu.

Autorskie antologie przekładowe - które w dużej mierze ciążą na polskiej recepcji rosyjskojęzycznej poezji - nie eksponują poezji kobiet, w żaden sposób nie podkre-

4 Przywołane wypowiedzi pochodzą z serwisu internetowego The devochki (http://thedevochki. $\mathrm{com} /$ ) - to witryna przypominająca czasopismo kulturalne, poświęcona szeroko pojętej kulturze i promująca aktywne kobiety - na temat poezji kobiet wypowiedziały się młode poetki, dziennikarki, osoby ze świata kultury - uczestnicy Tygodnia Poezji w Kijowie. 
ślają jej specyfiki, nie przejawiają też szczególnego zainteresowania losem zwierząt. To, co we współczesnej liryce rosyjskiej jest interesujące dla tłumaczy i badaczy, dotyczy przede wszystkim szeroko pojętej problematyki egzystencjalnej i społecznej. W wydanej w 2006 roku antologii Wiktora Woroszylskiego Moi Moskale. Wybór przekładów z poezji rosyjskiej od Puszkina do Ratuszyńskiej twórczość wymienionej w tytule Ireny Ratuszyńskiej, postrzeganą jako swoisty punkt dojścia i finał pewnej linii rozwojowej, reprezentuje wiersz o znaczącym incipicie Mój ty kraju znienawidzony!, reprezentatywny dla poetki podejmującej problemy martyrologii narodowej, patriotyzmu i związanego z tym pragnienia wolności. Tłumacz poświęcił uwagę jeszcze kilku poetkom (w antologii pojawiły się takie nazwiska jak: Bella Achmadulina, Natalia Gorbaniewska, Weronika Dolina, Natalia Astafiewa), zasadniczo jednak w doborze tekstów pominięto ostatnie trzy dekady. Woroszylski świadomie skoncentrował się na poezji zaangażowanej, z największym, jak się zdaje, upodobaniem tłumacząc wiersze dotyczące relacji polsko-rosyjskich, poszukiwania korzeni, rekonstruowania tożsamości i odczytywania zawikłanej przeszłości. W opowieści o historii narodu nie ma miejsca na opowieść o zwierzętach, a globalna perspektywa historyczna uniemożliwia uruchomienie spojrzeń innych, bardziej niszowych, nieantropocentrycznych.

$\mathrm{W}$ antologii Jerzego Czecha - zgodnie z deklaracją tłumacza - znalazło się niemało wierszy o charakterze metapoetyckim, rozważających powinności i możliwości poezji, poddających próbie granice i wytrzymałość języka. Dominuje w nich jednak tak charakterystyczna dla najnowszej poezji rosyjskiej tematyka społeczna połączona z refleksją egzystencjalną. Pragnienie wolności, poszukiwanie tożsamości, głód metafizyki, trudny patriotyzm - to tematy, które bardzo silnie rysują się $\mathrm{w}$ poezji rosyjskiej w perspektywie jednostkowej i w ujęciu dotyczącym zbiorowości, pozostają niezależne od płci autorów, pozostawiają niewiele miejsca na rozważania prowadzone $\mathrm{z}$ nieantropocentrycznej perspektywy, spychają $\mathrm{w}$ niszę poetki rezygnujące z globalnego oglądu. Wyobrażenie o zakresie tematycznym antologii Czecha daje już przywołanie kilku tytułów zamieszczonych tam wierszy: Aleksandr Makarow-Korotkow, ${ }^{* * *}$ Co my tu w Rosji umiemy...; Igor Irtieniew, Staruszka śmietnik przeszukała; Timur Kibirow, Kiedy Lenin byt maty; Iwan Achmietjew, *** broń jadrowa jest nam potrzebna; Dimitrij Prigow, ${ }^{* * *}$ W bufecie Domu Literata; Wsiewłod Niekrasow, ${ }^{* * *}$ ładna ta Moskwa...; Władimir Ufland, Opowieść pogranicznika.

Wiele rosyjskich poetek doskonale wpisuje się $\mathrm{w}$ patriarchalny model poezji, nie wprowadzając programowo do swojej twórczości cech zwyczajowo już traktowanych jako literackie wyróżniki kobiecości. Na przykład liryka Reginy Derievej postrzegana jest jako męska z uwagi na żelazną logikę i dlatego że odznacza się - jak pisze jedna z badaczek - „męską kanciastością paradosku i 'muskularnością' słownictwa, kiedy słowa uderzając o siebie stwarzają niepowtarzalny 'ciężki' rytm" (Derieva 11). To hermetyczna poezja, oparta na dialogu z kulturą, zakorzeniona w tradycji. Nie ma w niej miejsca na perspektywę posthumanistyczną. Derieva w tradycyjnym konflikcie natury i kultury zdecydowanie opowiada się po stronie kultury, która w jej liryce po- 
zwala człowiekowi budować i zachować tożsamość i samoświadomość. Zwierzęta są tu raczej elementami metafor czy alegorii, jak w wierszu o incipicie Po co było uczyć się języka, gdzie arka Noego staje się obrazem współczesnego, wrogiego społeczeństwa:

\author{
Po co było żyć \\ wśród zwierząt arki Noego, \\ które dopiero co zżarły \\ ostatniego gołębia pokoju, \\ a razem $\mathrm{z}$ nim samego Noego \\ i jego cnotliwą rodziną.
}

(Derieva 45)

Wiersz prowokuje do ironicznych odczytań. Kojarzące się z obchodami socjalistycznych świąt gołębie pokoju były wszak znakiem pełnym obłudy, może więc i cnota rodziny Noego podszyta jest hipokryzją, a europejska demokracja rozczarowuje brakiem więzi międzyludzkich i wzajemnym wrogim nastawieniem? Poetka - nawet kreśląc obraz arki pełnej zwierząt - pisze o cierpieniu ludzi. Opisuje cierpienie bohaterów biblijnych, mitologicznych, ofiar kolejnych wojen i systemów politycznych, cierpienie ludzi różnych nacji i wyznań. Pokazuje jego uniwersalny i ponadczasowy charakter, wskazuje cierpienie jako wyróżnik ludzkiej kondycji, niezbywalny element ludzkiego losu. To właśnie świadome przeżywanie cierpienia różni człowieka od zwierząt i czyni go wyjątkowym w świecie przyrody.

Podobnie dzieje się u Olgi Siedakowej - cierpienie jest przymiotem ludzi, nie zwierząt. Charakterystyczny dla tej poezji obraz niefrasobliwego bytu ptaków i innych stworzeń pojawia się między innymi w wierszu (z cyklu Trzy wiersze dla Jana Pawła II) Sant Alessio. Roma (Lewicka red. 105), który otwiera apostrofa do jaskółek. Ich wolny od trosk żywot (fruwają po Awentynie, po Rzymie, wśród pomarańczy i pinii) zostaje kontrastowo zestawiony z dolą ludzką, której ucieleśnieniem jest los syna marnotrawnego. „Wrzody, kości, / suche kości, jak w dolinie Jozafata” (Lewicka red. 107), szeroko pojęte cierpienie mają sens tylko w ludzkim porządku. Nie stają się udziałem jaskółek. Podmiot liryczny powiada:

\footnotetext{
kiedy tak sobie fruwacie

nie wiadomo skąd nie wiadomo dokąd

mijając gałęzie pomarańczy i pinii...

syn marnotrawny wraca do domu rodzinnego

co stary jest i głęboki jak woda w studni.

(Lewicka red. 105)
}

Przyroda - ożywiona i nieożywiona - w najnowszej rosyjskiej poezji kobiet często przywoływana jest metaforycznie lub stanowi tło dla ludzkich emocji. Prze- 
miany pór roku, rozgwieżdżone niebo, wiatr, a zwłaszcza roziskrzony, skrzypiący pod stopami śnieg ukazują piękno i potęgę natury, stają się przyczyną rozmaitych refleksji, generują poczucie radości życia, przemijania, współodczuwania z naturą. W wierszu Larysy Jegorowej śnieg, zdrobniale nazywany śnieżkiem (w oryginale mowa o śnieżynkach), zasypuje brzydotę świata. Kiedy znika i topnieje, to co brzydkie znów zostaje odsłonięte, a jedynym wspomnieniem po uroku śnieżynek pozostaje przemoczona odzież i przeziębienie bohaterki lirycznej. Kontakt z przyrodą sprzyja uniesieniom, ale ich konsekwencje są nad wyraz przyziemne (Pierwszy śnieg, Lewicka red. 27). Także w wierszu Olgi Harłamowej śnieżyca cieszy, jeśli można się w niej zapodziać wraz z ukochanym (Śnieżyca, Śnieżynka, Lewicka red. 23, 41).

Zdecydowanie najważniejszym, podkreślanym przez poetki ostatnich dekad, wyodrębnionym ze świata natury elementem, są jednak drzewa - obdarzone emocjami, dzielące ludzkie losy, nierzadko zrównane z ludźmi w swych doświadczeniach i przeżyciach. W poezji Lubow Salomon kasztany, na które zaprojektowano ludzkie emocje, wołają i błagają szmerem swoich gałęzi oraz trwożą się, przeczuwając nadchodzące nieszczęścia (Lewicka red. 79). Podobnie funkcjonującej personifikacji poddana została wierzba z wiersza Wierzba płacząca (Lewicka red. 85) - smutna kochanka księżyca.

Olga Lewicka ${ }^{5} \mathrm{w}$ wierszu Brzózki opisuje powinowactwo kobiety i drzew - tytułowych brzóz rosnących i w Polsce, i w Rosji. Pokrewna drzewom bohaterka liryczna łączy miłość do Polski i Rosji, podobnie jak autorka wiersza. Szpaler polskich brzóz wywołuje w niej wspomnienia i tęsknotę za ojczyzną dzieciństwa - „I powieje nagle od drzewek / dawnym życiem, daleką Rosją" (Lewicka red. 121).

Również w poezji Marii Stiepanowej znajdziemy charakterystyczny dla poezji rosyjskiej motyw drzewa spowinowaconego z człowiekiem. W wierszu o incipicie To drzewo tak się do mnie garnie bohaterka liryczna pozostaje $\mathrm{w}$ intymnym, bliskim związku z drzewem. Mówi:

To drzewo tak się do mnie garnie,

Jakby nas wczoraj pożenili.

$[\ldots]$

Kto ze mną, głupio jest nie wiedzieć.

Raczej nie lipa, tylko topól,

Tak ciasno mnie oblepiasz wokół

I tak wspaniale się kolebiesz.

(Lewicka red. 145) ${ }^{6}$

5 Wiersz ma charakter autobiograficzny - jego autorka, Olga Lewicka, urodziła się nieopodal Kurska, w Polsce mieszka od 1977 roku.

6 Tu nie po raz pierwszy przypomina mi się scena z filmu Fortepian, kiedy córka głównej bohaterki przytula się do drzew, rosnących na tajemniczej wyspie, a dziecięcy erotyzm i panerotyzm natury przenikają się wzajemnie. 
Bohaterka liryku Stiepanowej rezygnuje jednak z dziwnego, wspaniałego, ale i opresyjnego związku (określenie "ciasno mnie oblepiasz" ma w sobie coś niepokojącego i sugeruje zniewolenie) - mówi:

Wyciągam się, zmartwiała, blada,

Od serca oderwawszy korzeń,

Z gałęzi jak wiewiórka spadam.

(Lewicka red. 145)

W poezji Tatiany Olejnikovej drzewa są alegoriami ludzi. W wierszu o incipicie Przez ciężkie brzemię... stare topole pozostają obarczone doświadczeniem lęku, a młody pęd rośnie pełen ufności do świata.

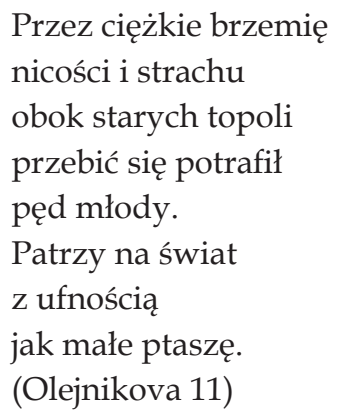

Wydaje się więc, że w polskiej i rosyjskiej kulturze zupełnie inaczej postrzega się przekroczenie granic międzygatunkowych. Polska poezja kobiet postrzega świat z perspektywy jednostki, którą coraz częściej jest byt nie-ludzki. Na obraz całości składają się bowiem spojrzenia pojedynczych istot, reprezentujących różne - nie tylko antropocentryczne - sposoby myślenia. W rosyjskiej poezji kobiet dużo istotniejsze od indywidualnej perspektywy pozostają relacje jednostki ze społeczeństwem, napięcie pomiędzy własną percepcją a świadomością zbiorową. Źródłem inspiracji rosyjskich poetek rzadko bywają zderzenia różnych ujęć jednostkowych (na przykład sposób przeżywania podobnego doświadczenia przez przedstawicieli różnych płci, grup społecznych czy różnych gatunków), jest nim raczej nieustanne ścieranie sięjednostki i ogółu (na przykład sposób postrzegania różnorodnych sytuacji właściwy dla konkretnego człowieka z odczuciem przypisywanym całej społeczności, narodowi, wspólnocie). W polskiej poezji kobiet bohaterki liryczne określają swoją tożsamość wobec innych zindywidualizowanych bytów. W rosyjskiej poezji (nie tylko pisanej przez kobiety, bo omawiane zjawisko dotyczy również twórczości poetów) indywidualna tożsamość konstytuuje się wobec swego rodzaju tożsamości zbiorowej.

Pozostaje pytanie, co będzie dalej. Jaka przyszłość stoi przed posthumanizmem? Czy są jakieś zwiastuny, które pozwalają przewidzieć, jak będzie ewoluował obraz 
cierpienia zwierząt $\mathrm{w}$ poezji, literaturze, kulturze? Czy te same tendencje zdeterminują rozwój posthumanistycznych perspektyw w poezji polskiej i rosyjskiej? Czy jak można się zastanawiać, interpretując ostatnie wiersze Szymborskiej - założenia posthumanizmu odniesiemy także do maszyn, przyznając im prawo do myślenia, odczuwania i ostatecznie cierpienia? Czy odejście od antropocentryzmu i dążenie do zrównania człowieka ze zwierzętami przekroczy kulturowe tabu, ocierając się o granice sodomii (jak w twórczości Olega Kulika)? Być może bardziej szczegółowe badania literackich obrazów cierpienia zwierząt pozwolą rozstrzygnąć te kwestie i odkryć główne tendencje rozwoju posthumanistycznej kultury.

\section{BIBLIOGRAFIA}

Bańko, Maria. [Wypowiedź na temat Tygodnia Poezji w Kijowie]. The devochki. Web. 20.02.2016. $<$ http://thedevochki.com/>

Czech, Jerzy. Wdrapatem się na piedestat. Nowa poezja rosyjska. Wołowiec: Wydawnictwo Czarne, 2013.

Derieva, Regina. Chleb i sól. Przeł. Ryszard J. Reisner. Poznań: Wydawnictwo Warszawskiej Prowincji Karmelitów Bosych, 2015.

Foucault, Michel. Stowa i rzeczy. Archeologia nauk humanistycznych. Przeł. Tadeusz Komendant. Gdańsk: słowo/obraz/terytoria, 2005.

Galant, Arleta. Polowania i linienia. Śmierć zwierzat w wybranej prozie kobiet. W zb. Twórczość niepozorna, red. J. Grądziel-Wójcik, A. Kwiatkowska, L. Marzec, Kraków 2015, s. 249-259.

Kraskowska, Ewa. Czytelnik jako kobieta. Poznań: Wydawnictwo Naukowe UAM, 2007.

Lewicka Olga, red. Wspótcześni poeci rosyjscy. Przeł. Olga Lewicka. Lublin: Wydawnictwo Episteme, 2014.

Ładyga Zuzanna, Włodarczyk Justyna, red. Po humanizmie. Od technokrytyki do animal studies. Gdańsk: Wydawnictwo Naukowe Katedra, 2015.

Olejnikova, Tatiana. Wróżę z dłoni kobiecej. Przeł. Teresa Nietyksza. Opole [brak wydawnictwa], 2012.

Tokarczuk, Olga. Moment niedźwiedzia. Warszawa: Wydawnictwo Krytyki Politycznej, 2012.

Woroszylski, Wiktor. Moi Moskale. Wybór przekładów z poezji rosyjskiej od Puszkina do Ratuszyńskiej. Wrocław: Biuro Literackie, 2006. 